\title{
Female university student's ICT learning strategies and their influence on digital competence
}

Open Access

\author{
Rocío Jiménez-Cortés ${ }^{*}$ D, Alba Vico-Bosch and Angeles Rebollo-Catalán
}

\footnotetext{
*Correspondence: rjimenez@us.es Department of Research Methods \& Diagnostic in Education, Faculty of Education, University of Seville, c/ Pirotecnia, s/n, Seville (E-41013), Spain
}

\begin{abstract}
Emerging technologies are leading to a rethink informal education and giving rise to new educational models, especially at university level. This paper looks into the strategies used by female university students to learn ICT and how this influences their level of digital competence. To do this, we surveyed 368 Spanish university women aged 20 to 34, using two scales measuring their learning strategies and digital skills. The findings showed that university students used a variety of strategies to learn about ICT, with strategies based on independent and collaborative learning prevailing. Results also showed that those women who used a wider variety of strategies to learn ICT attained more advanced digital skills. These results suggest the need to incorporate these forms of learning used by women with advanced digital skills into university teaching.
\end{abstract}

Keywords: Digital competence, Learning strategies, Internet, University students, Women's studies

\section{Introduction}

The 2020 digital agenda underlines the wealth of opportunity opened up by the digital age for creating new educational scenarios and strategies. The Horizon Report (Johnson, Adams Becker, Estrada, \& Freeman, 2015) emphasizes that education needs to review educational scenarios, making them more flexible and adapting them to digital technologies. Ferrari (2012) reiterates the importance of incorporating digital technologies into educational processes because they provide benefits for teaching and learning, capacitate in fundamental digital competences which are central to personal development in today's society and help close the digital gap through digital inclusion.

The inclusion of new technologies in everyday-life is revolutionizing learning paradigms and leading to a revision of models of university education in the light of new pedagogical theories. These pedagogies constitute nascent approaches to education which are emerging around the use of digital technologies to fully exploit its communicative, informational, collaborative, interactive, creative and innovative potential in a new learning culture (Adell \& Castañeda, 2012, p. 15). According to Gros (2015), these emerging pedagogies are based as much on classical pedagogical theories as they are on present-day perspectives. Thus, invisible learning (Cobo \& Moravec, 2011), rhyzomatic learning (Cormier, 2008), connectivism (Siemens, 2005) or ubiquitous learning

(c) The Author(s). 2017 Open Access This article is distributed under the terms of the Creative Commons Attribution 4.0 International License (http://creativecommons.org/licenses/by/4.0/), which permits unrestricted use, distribution, and reproduction in any medium provided you give appropriate credit to the original author(s) and the source, provide a link to the Creative Commons license, and indicate if changes were made. 
(Cope \& Kalantzis, 2009), amongst others, are leading the way as incipient theories supporting new pedagogical theories. However, some of these nascent theories have come under fire (Zapata-Ros, 2015) due to insufficient explanation of the learning process.

Invisible learning is considered a socio-technological framework that understands learning as a continuum throughout life and can occur at any time or place. This approach promotes learning strategies designed to combine formal learning with formal and informal. The rhizomatic learning refers to knowledge produced in community, which is negotiated and based on self-interest, personal needs and motivations. The connectivism, refers to the construction a self-organizing learning system and changing activities, individuals and communities. This approach focuses on the ability to create connections between sources of information as a way to manage knowledge. Ubiquitous learning is that which occurs at anytime and anywhere, refers to the spaces and times of learning. Although these theories are similar in terms of the learning processes characteristics in the digital age (such as autonomy, uncertainty) do not provide knowledge about how learning occurs.

Cabero and Llorente (2015) went back to self-regulated learning theory to explain and analyze the incorporation of ICT into learning processes. ICTs provide a wealth of possibilities for the design of new learning spaces, situating students in the centre of the learning process, where they regulate and organize their learning themselves. The authors' approach to self-regulated learning highlights the importance of the application of learning strategies. However, the potential for technologies to foster learning self-regulation processes in students and the deployment of learning strategies requires a suitable technopedagogic design of tasks and activities, not just depending on ICT characteristics (Area, 2007). The uses to be given to ICT depend on the technopedagogical design of teaching and learning in which technological resources available are framed (Coll, Engel, Saz, \& Bustos, 2014). Virtual environments difficult allow or promote certain forms of teaching and learning (Onrubia, 2005). The new pedagogies, those that are under development, must help design spaces and activities geared towards different forms of learning of university students.

The empirical studies being developed from these nascent theories are still few in number, but current trials and reviews (Cabero \& Llorente, 2015) underline the relevance of strategies for learning with technologies as central dimensions for redirecting educational processes, particularly in the university setting. For Gros (2015), people need to develop important skills to direct their educational processes, but these skills develop at an earlier stage, they are not acquired spontaneously. This author argues that university education should not just be aimed at developing competences in the framework of disciplines but also at preparing in competences which will enable them to cross over diverse spaces without having a fragmented and disperse experience. Hence, university pedagogical models must be sensitive to the variety of strategies for learning arising with new digital technologies, with particular attention paid to those which encourage skills in advanced digital competences (Rebollo-Catalán, Mayor-Buzón, \& García-Pérez, 2015).

The inclusion of ICTs requires a re-think in education, both in the ways people teach and the ways people learn, seeing this as a necessary and irreversible transition in the current university context (Escofet, Albert, \& Vilá, 2008). Maquilón, Mirete, García-Sánchez, and Hernández (2013) demonstrated that the way students view their 
learning process determines the learning approach (combination of motivation and strategies) they adopt to overcome the academic challenges they face during their education.

Current research into women and technologies is aimed at understanding what use women make of ICTs to understand the relations between uses and learning processes in the academic setting. The study by Rebollo-Catalán, Vico-Bosch, and García-Pérez (2015), which focused on the use of social networks, shows that women lean more towards informal contexts than formal ones, looking for help from friends or family or using virtual resources (YouTube tutorials, specialist websites or forums) to learn more about ICT. It also demonstrates that they use more autonomous learning strategies based on experimentation with the technology than collaborative learning strategies through participation in groups, associations or projects, or conventional strategies such as taking a course.

Several studies (Aesaert \& van Braak, 2015; Sánchez-Vadillo, Ortega-Esteban, \& Vall-llovera, 2012) have analyzed the factors which influence digital competences from a gender perspective. Sánchez-Vadillo et al. (2012) indicate that, in ICT learning, influence is drawn from the nearest models and references (family and school/ teachers), and the means of communication and girls' expectations. These authors state that gender stereotypes may be contributing to the disaffection of women with the technological world, leading to a lack of motivation towards their professional capacitation and personal aspirations. However, the study by García-González, Gros, and Escofet (2012) offers novel findings about gender stereotypes associated to the use of technology, showing that university women perceive themselves to be very competent in the informal use of ICTs in the settings where they use them most, opting for a more academic and informational use oriented towards a more participative and communicative pedagogy. In the same vein, Vergés, Hache, and Cruells (2011) argue that, when analyzing women's experiences and their inclusion in ICTs, the tremendous scope for informal learning made possible by the internet has to be taken into account. The study emphasizes that women are enthusiastic about ICT and they use a variety of strategies linked to both formal and informal learning.

Other studies point to a high perception of female university students in terms of digital competences. According to Rebollo-Catalán, Mayor-Buzón, et al. (2015), women learn using a wide variety of learning contexts and resources and in so doing they reach an advanced level of digital competence in the networks. In turn, the study by GarcíaGonzález et al. (2012) also shows that basic digital competences are not necessarily transferred to the use of technology for educational purposes. One could say that the diversity of technologies that are used informally are not used in university education. The recent study by Jiménez-Cortés (2015), focusing on the ubiquitous learning of women in social networks, highlights that a large percentage of young women do not often use these digital technologies during their university academic activity, instead they prefer to use them at other times.

Advanced digital competences in the creation and exchange of contents on the internet and social networks have been identified by other studies as another important line of research related to the development of new pedagogies. This area is producing digital gaps with implications for university education. Margaryan, Littlejohn, and Vojt (2011) point to the lack of familiarity in the use of tools to create collaborative knowledge, 
virtual worlds, publication of personal websites and other new social technologies, and their application to learning practices. These competences related to the production of knowledge are highlighted by the new pedagogies, which encourage an intense use of technologies (Gros, 2015).

Our study focuses on learning strategies and their influence on the digital competence of female university students. We therefore propose as objectives:

1. Describe the strategies female students use to learn ICTs.

2. Gauge the degree and type of digital competence that female university students show in internet use.

3. Identify profiles of women according to their ICT learning strategies.

4. Analyze the influence of women's ICT learning strategies on digital competence.

\section{Method}

\section{Participants}

From a previous study sample of 1340 female participants, this study selected 368 female university students aged between 20 and 34. They had 1 year's minimum experience in the use of a virtual social network, and they were selected using quota sampling, taking into account age and place of residence.

As for their technological profile, we found that over $90 \%$ of the women had more than 5 years experience in internet use, with a daily use frequency above $95 \%$. We also found that around $55 \%$ of the women had recently received internet training, with this training being mainly formal (73.6\%) as opposed to informal (21.2\%). Table 1 shows the women's profiles in internet use and training.

\section{Instrument and measures}

We used a questionnaire to perform the study; it contained the following measures and variables:

1. Sociodemographic variables and use of technologies. This included questions about age, the region they were from, place of residence, whether they had children, current employment situation and questions related to experience and frequency of use and recent internet training (last 3 years) and type of training.

Table 1 Technological profile of participants

\begin{tabular}{lllr}
\hline Variables & Categories & $f$ & Percent \\
\hline Experience in internet use & $1-5$ years & 23 & 6.3 \\
& More than 5 years & 344 & 93.7 \\
Frequency of internet use & More than once a week & 5 & 1.4 \\
& Daily & 362 & 98.6 \\
Recent internet training (last three years) & No & 162 & 44.3 \\
& Yes & 204 & 55.7 \\
Type of training & Formal & 153 & 73.6 \\
& Informal & 44 & 21.2 \\
& Formal and informal & 11 & 5.3 \\
\hline
\end{tabular}


2. Learning strategies scale. This was elaborated "ad hoc" from previous studies (Rosenthal, 2008; Vergés et al., 2011), and it consisted of 10 items on a four point Likert scale (from 0 -not at all- to 3 -a lot-). It included the different forms of learning ICT preferred by the women, incorporating different modalities of training, from the most conventional based on performing courses to strategies involving self-directed learning. This scale presents a high reliability (Cronbach's Alpha of 0.883 ) and high rates of saturation of all the items in the main component.

3. Internet digital skills scale, designed ad hoc from the contributions of Van Deursen, Helsper, and Eynon (2014) and the UK government's technical report(2012). It consists of 18 items on a four point Likert type response scale (from 0 -neverto 3 -always-). This scale presents a high reliability (Cronbach's Alpha of 0.907) and high rates of saturation of all the items in the main component.

\section{Procedure}

For the selection, location and surveying of the women we collaborated with the Andalusian Women's Institute and other women's organizations in Andalusia and Extremadura (AUPEX) who facilitated our access to the women. The online version of the survey (made available using the Google Form application) included an informed consent section which had to be accepted before they could fill in the questionnaire. The researchers responsible for data collection and coordinating the study were bound by a declaration of confidentiality and the work was conducted between April and September 2015.

We analyzed the data using the SPSS v.21 statistical package, applying exploratory techniques to the variables to identify the characteristics of their distribution and validity and reliability tests of the measures used.

To explain the types of learning strategies that university women use, we applied a factorial analysis of the main components with a varimax rotation to the measure of the learning strategies determining three factors which explain $73.06 \%$ of the total variance $(51.1 \%$ factor $1 ; 13.68 \%$ factor $2 ; 8.28 \%$ factor 3$)$. The reliability analysis produced a Cronbach's alpha of 0.915 for factor 1 (conventional), 0.776 for factor 2 (autonomous) and 0.687 for factor 3 (collaborative). Tables 2 and 3 shows that all the items obtained factorial weights over 0.50 , assigning them to the factor with the highest value.

Table 2 Rotated component matrix of learning strategies

\begin{tabular}{|c|c|c|c|}
\hline Items & $\begin{array}{l}\text { Factor } 1 \\
\text { Conventional } \\
\text { Learning }\end{array}$ & $\begin{array}{l}\text { Factor } 2 \\
\text { Collaborative } \\
\text { Learning }\end{array}$ & $\begin{array}{l}\text { Factor } 3 \\
\text { Autonomous } \\
\text { Learning }\end{array}$ \\
\hline 5. Attend courses on specific and useful tools and applications & .909 & .169 & .084 \\
\hline 4. Follow virtual courses which allow me to apply what I learn & .862 & .173 & .191 \\
\hline $\begin{array}{l}\text { 8. Attend courses about how things work at a basic level and } \\
\text { then continue learning on my own }\end{array}$ & .823 & .359 & .027 \\
\hline $\begin{array}{l}\text { 10. Take part in activities organized by associations and groups } \\
\text { which I know }\end{array}$ & .777 & .410 & .092 \\
\hline 9. Talk to other people in forums and groups & .170 & .780 & .145 \\
\hline 1. Take part in common projects with other people & .260 & .703 & .129 \\
\hline 6. Form part of a group or community which makes me feel supported & .569 & .635 & .083 \\
\hline 7. Talk to an expert who can advise me & .453 & .508 & .268 \\
\hline 3. Use technology intuitively because I like experimenting & .150 & .035 & .882 \\
\hline 2. Try and test while doing things I like & .048 & .291 & .809 \\
\hline
\end{tabular}


Table 3 Results of the partition in four clusters and exploratory ANOVA

\begin{tabular}{|c|c|c|c|c|c|c|c|c|c|c|}
\hline \multirow{3}{*}{$\begin{array}{l}\text { Final cluster groups ( } 4 \text { groups) } \\
\text { Factors of learning strategies }\end{array}$} & \multirow[b]{3}{*}{1} & \multirow[b]{3}{*}{2} & \multirow[b]{3}{*}{3} & \multirow[b]{3}{*}{4} & \multicolumn{6}{|l|}{ Anova } \\
\hline & & & & & \multicolumn{2}{|l|}{ Cluster } & \multicolumn{2}{|l|}{ Error } & \multirow[t]{2}{*}{$F$} & \multirow[t]{2}{*}{ Sig. } \\
\hline & & & & & Quadratic mean & $\mathrm{Gl}$ & Quadratic mean & $\mathrm{Gl}$ & & \\
\hline F 1. Conventional & 10 & 1 & 7 & 2 & 852.649 & 3 & 2.337 & 211 & 364.789 & 0.000 \\
\hline F 2. Collaborative & 10 & 2 & 6 & 6 & 485.251 & 3 & 2.441 & 211 & 198.755 & 0.000 \\
\hline F 3. Autonomous & 5 & 4 & 4 & 4 & 18.263 & 3 & 1.777 & 211 & 10.277 & 0.000 \\
\hline
\end{tabular}

Once we had verified the unidimensionality of the internet digital competences scale, we calculated a global variable from the sum of items: "Degree of digital competence" $(0-54)$. For this paper, we have presented the results of global digital competence on a three point scale $(0-17=$ Basic; $18-35=$ Moderate; and, $36-54=$ Advanced $)$, after we had checked that this recoding had not affected its validity and reliability.

To establish female university students' learning strategies as a function of the factors observed on the ICT learning strategies scale, we conducted a $K$-means cluster analysis (Q-Cluster). We applied the Kolmogorov-Smirnov test which accepted the hypothesis of normality of distributions and an ANOVA parametric contrast test to find out whether there were significant differences in digital competence between women who had or had not received recent internet training. Finally, we applied cross comparison tables to forms of learning in ICT and the degree of digital competence.

\section{Results}

\section{Strategies used by female university students to learn ICT}

The female university students in our sample showed a preference for learning via autonomous and intuitive learning, as opposed to other types of formulas, and they did so experimenting with technologies (Fig. 1). The strategy used most was trying and

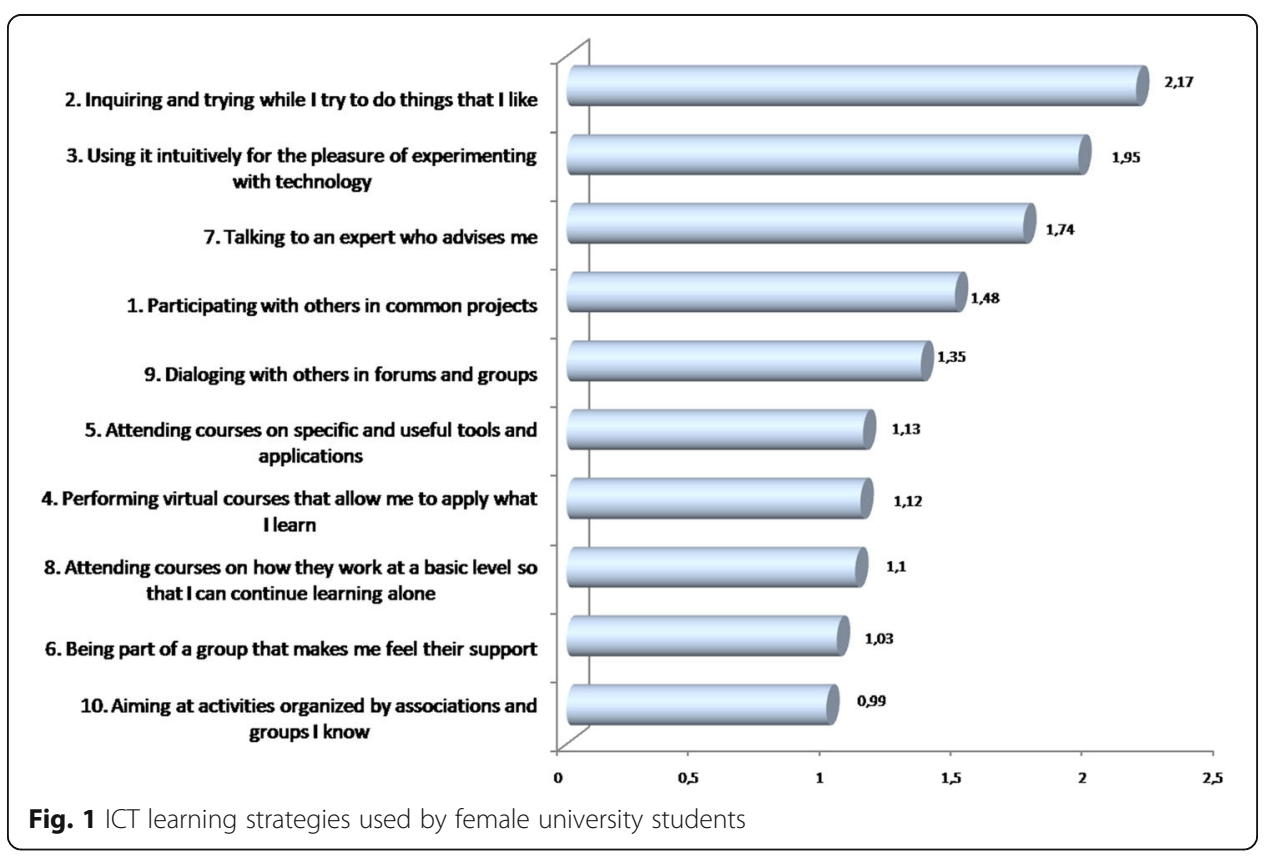




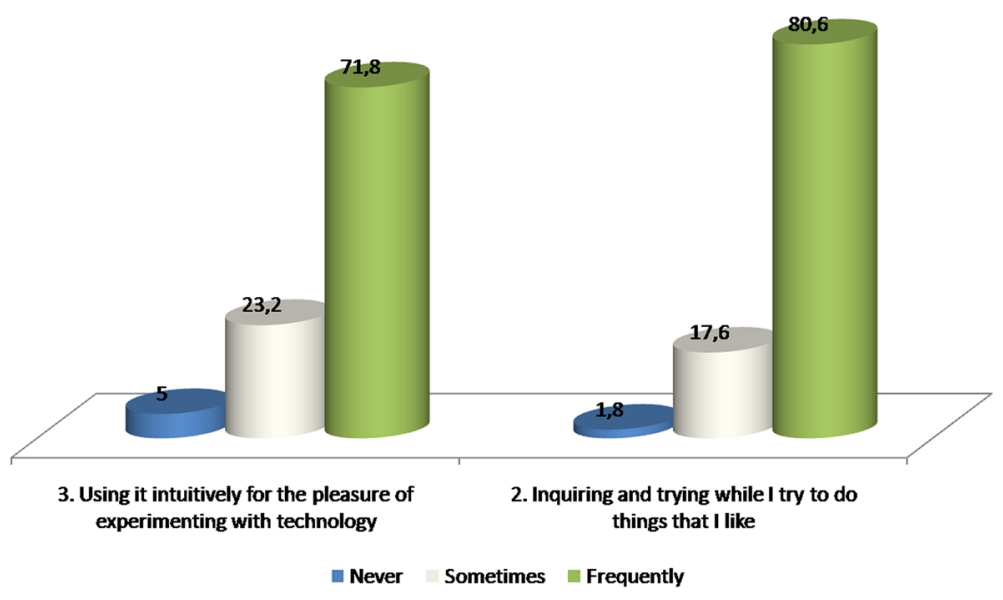

Fig. 2 Autonomous learning strategies

testing while doing things they liked $(M=2.17$; $\mathrm{SD}=0.777)$. In contrast, taking part in activities organized by associations and groups was the least used strategy $(M=0.99$; $\mathrm{SD}=1.025)$.

An analysis according to the type of learning strategies showed that, in relation to autonomous learning strategies, $80.6 \%$ of women frequently used the strategy of trying and testing while doing other things they liked. This strategy was used only sometimes by $17.6 \%$ of the sample. In turn, $71.8 \%$ used the tecnology intuitively for the pleasure of experimenting with it (Fig. 2).

As for collaborative learning strategies, $64.7 \%$ of the women preferred to talk to an expert for advice, and they followed this strategy often. A total of $37.4 \%$ would never choose to form part of a group or community to learn ICT, while $45.5 \%$ often used the strategy of participating with other people in common projects to learn ICT (Fig. 3).

In terms of conventional learning strategies, 35.3\% of female university students signed up frequently for courses on specific useful tools and applications, while $26.7 \%$ only used this strategy sometimes. It is interesting that $35.1 \%$ never learnt ICT and resorted to virtual courses (Fig. 4).

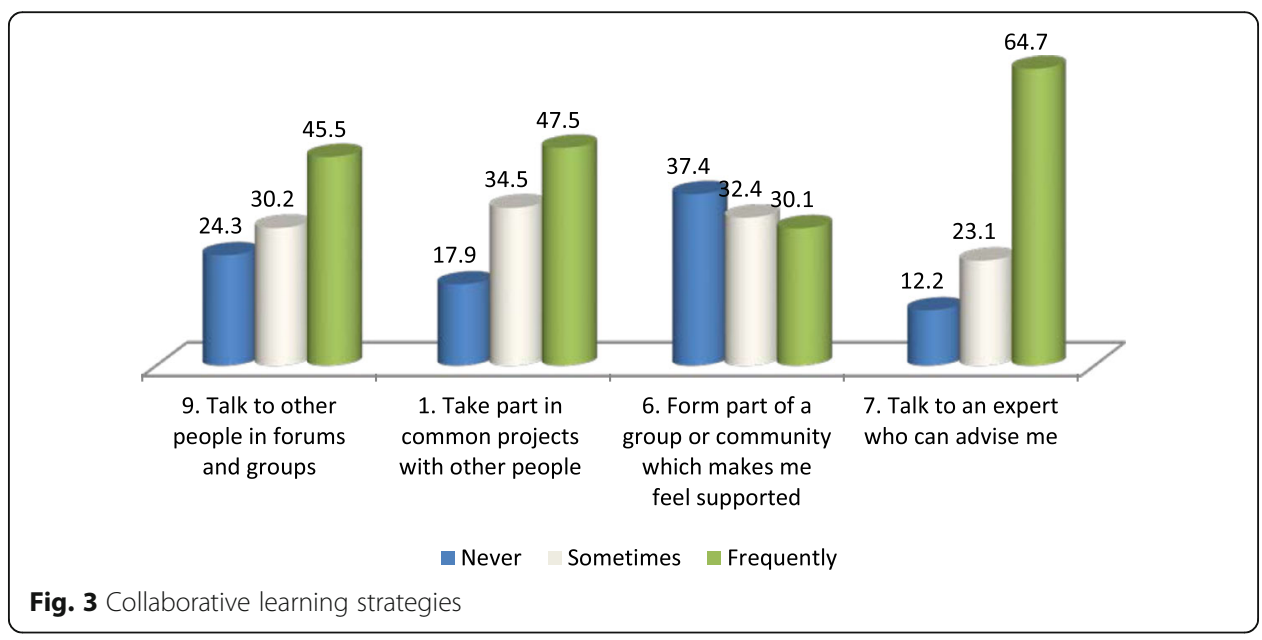




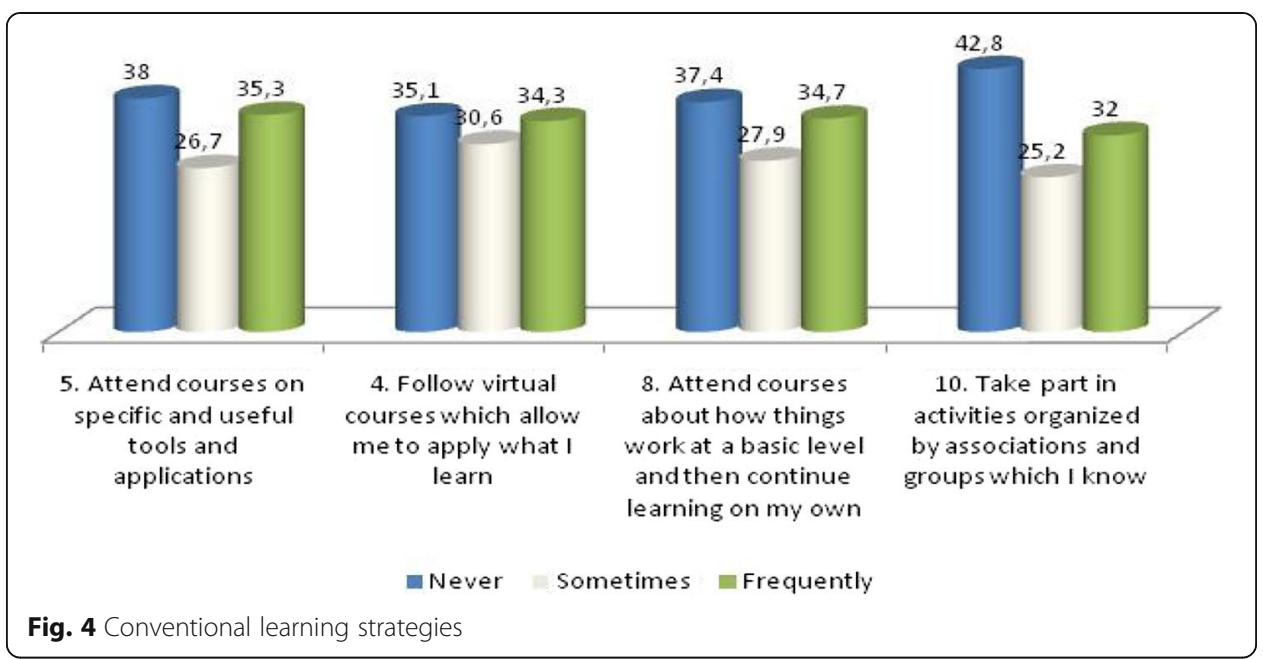

Degree and type of digital competence of female university students

As for the degree of digital competence, we found that $61.2 \%$ of the women had a moderate degree of digital competence, followed by $29.9 \%$ who showed an advanced level and only $8.9 \%$ showed a basic degree of digital competence.

Female university students stood out in 14 digital competencies, where they obtained above average scores (Fig. 5). Particularly noteworthy was their ability to use services such as Google to search for and find the information they needed $(M=2.82$; $\mathrm{SD}=0.453)$, and also skills in using email, video-conference, and instant messaging to communicate on the internet $(M=2.5$; $\mathrm{SD}=0.723)$, and skills for configuring privacy options to protect their personal data $(M=2.29 ; \mathrm{SD}=0.869)$. However, the results also reflected other competences in which they did not score so highly, with their ability

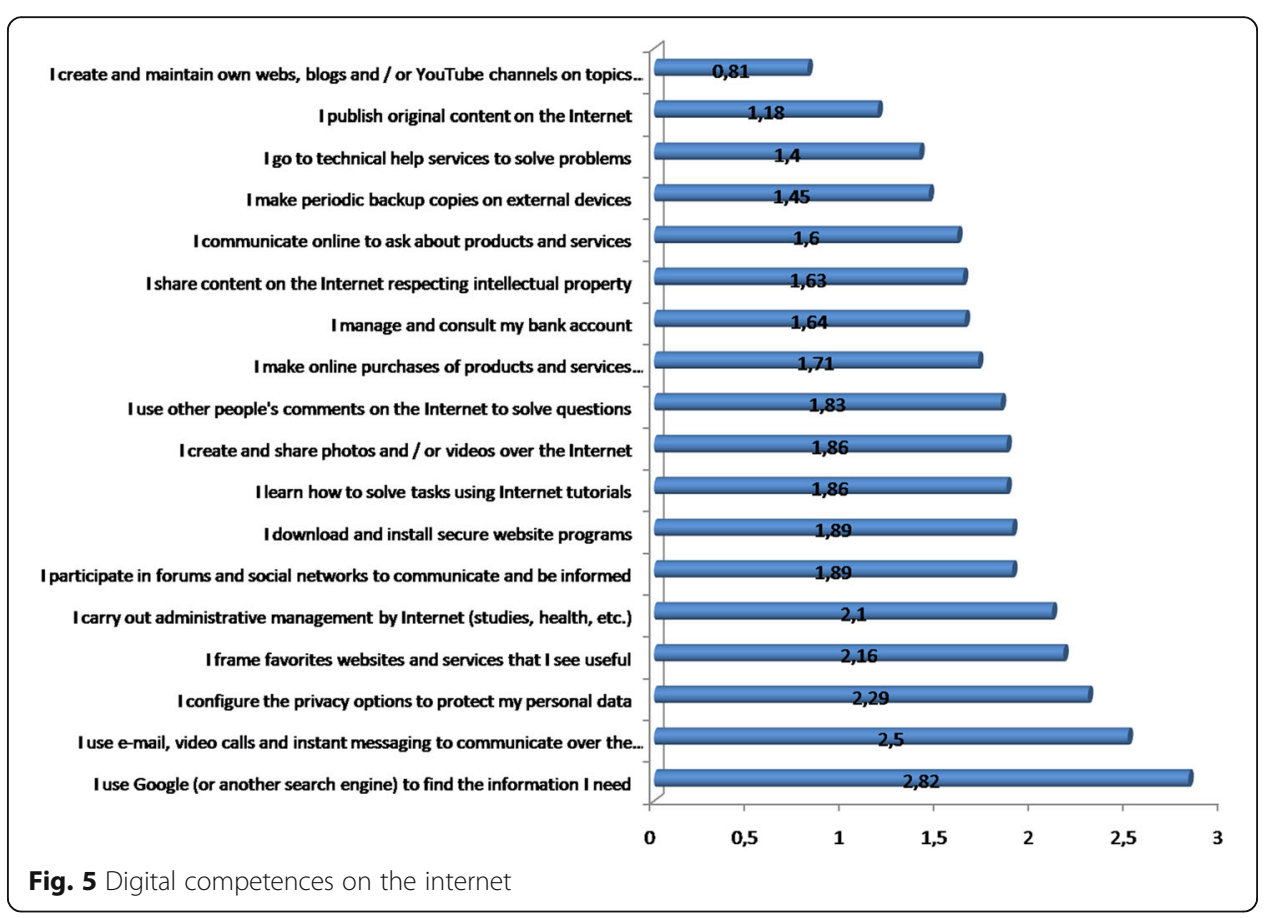


to create websites, blogs and/or YouTube channels standing out negatively $(M=0.81$; $\mathrm{SD}=1.002$ ).

The results showed significant differences in the degree of digital competence of the students depending on whether or not they had recently received internet training $(F=115,546, p=0.001)$. The women who had received recent training showed a higher degree of digital competence $(M=34.24, \mathrm{SD}=9.46)$ than those who had not $(M=30.76, \mathrm{SD}=9.69)$.

Female university students' learning strategies and their influence on digital competence on the internet

The results outlined four profiles in students' strategies for learning ICT. Group 1 (17.7\%), included women who "learnt intensively and expansively", who used a wide range of strategies (conventional, collaborative and autonomous) to learn, and did so frequently. Group 2 (33\%), "learnt in a self-directed way" driven by the pleasure of using technologies and experimenting with them. Group 3 (26.5\%) "learnt in a moderately expansive way", in other words, they used a diversity of strategies to learn ICT but with less intensity than Group 1. Group 4 (22.8\%) included women who "learnt in a collaborative and selfdirected way", using mainly the combination of both types of strategies.

Figure 6 shows the differences in digital competence depending on the ICT learning strategies used by the women, with those who learnt intensively and expansively being the ones who reached the highest level of digital competence $(M=42.394$.; $\mathrm{SD}=9.086)$. They were followed by those who learnt in a moderately expansive way $(M=36.193$, $\mathrm{SD}=9.519)$; with the women who only learnt autonomously scoring the lowest levels of digital competence $(M=31.873,=8.593)$.

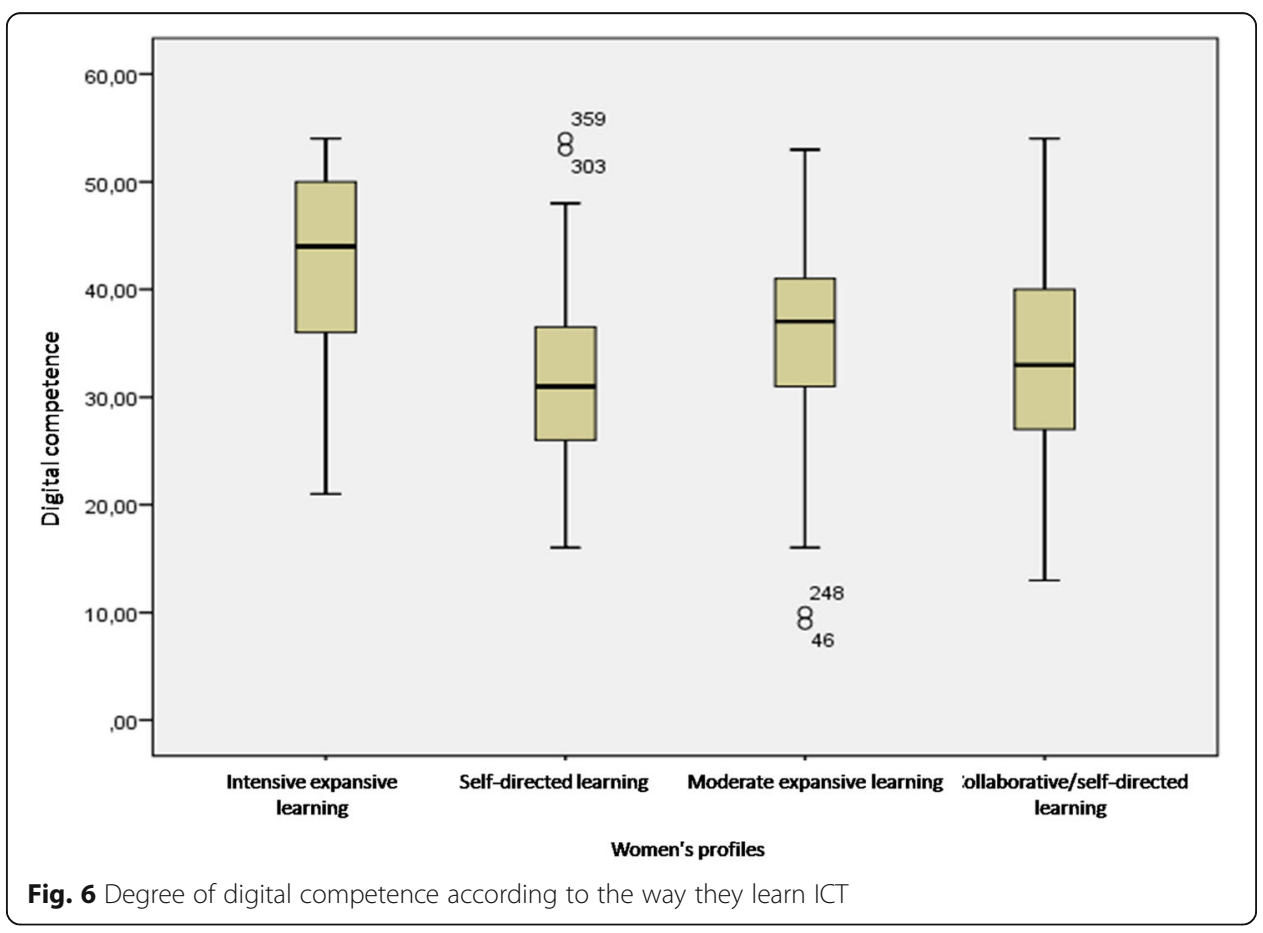




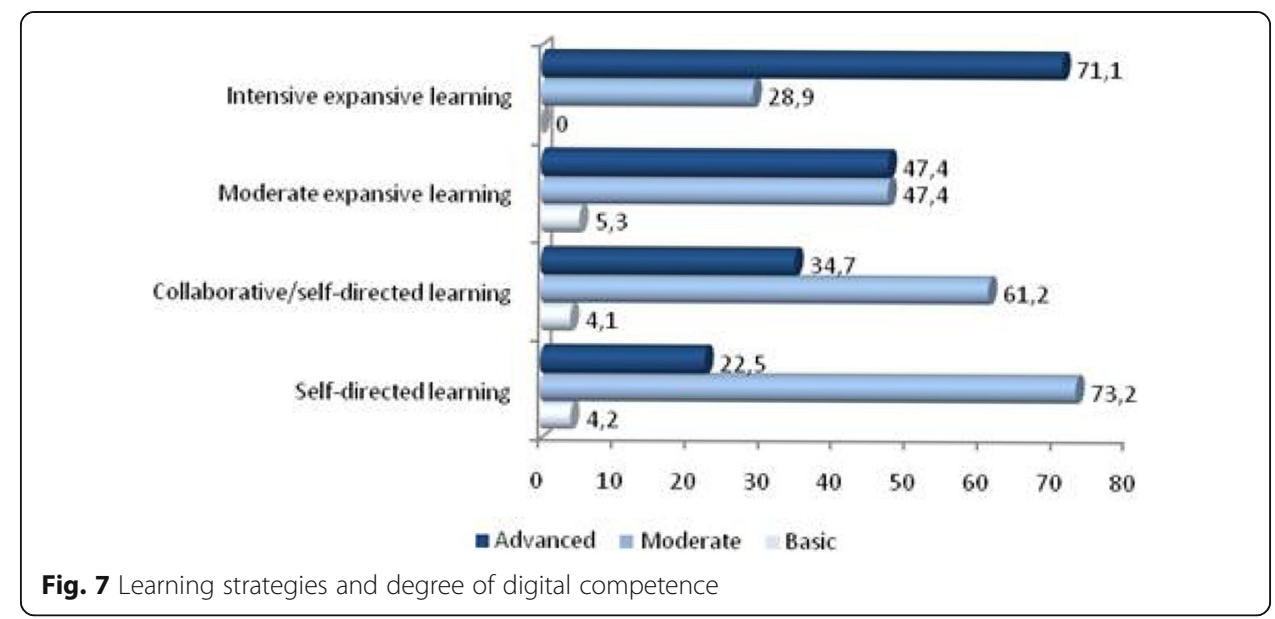

The advanced level of digital competence on the internet was reached with the use of both intensive and moderate types of expansive learning. In this sample, $71.1 \%$ of female university students who used a form of expansive and intensive learning obtained an advanced level in digital competence. This form of learning was characterized by the use of a broad diversity of learning strategies, including conventional, collaborative and autonomous strategies. The women who used these expansive learning strategies in ICT did not present basic levels of digital competence $(0 \%)$ and only $28.9 \%$ showed a moderate level of digital competence. Women who learnt expansively but moderately presented an advanced degree of digital competence.

The results showed that a high percentage of the women (73.2\%) who learnt following one single autonomous learning strategy reached a moderate level in digital competence, whereas $22.5 \%$ presented an advanced level. The use of combined collaborative and self-directed learning strategies gave the same percentages of women with a moderate $(47.4 \%)$ and advanced degree $(47.4 \%)$ of digital competence (Fig. 7).

The differences in the level of digital competence on the internet depending on the learning strategies used by the women to learn about technologies was significant as the contingency coefficient indicated $\left(X^{2}=27.108\right.$, contingency coefficient $=$ $0.335, p=0.000)$.

\section{Discussion and conclusions}

Women learn ICT using a diversity of learning strategies, including collaborative, autonomous and conventional styles, although they prefer to do so autonomously and intuitively for the pleasure of experimenting with ICTs. Recent studies (García-González et al., 2012; Vergés et al., 2011) have highlighted that women get more pleasure from their use of technologies, particularly when they want to learn more about them. In this sense our study offers novel findings about the gender stereotypes associated to the use of technology, in contrast to previous research which has emphasized a technophobic and pessimistic perception of how women relate to technologies, closely tied to the exclusion paradigm (Vergés, 2012). Autonomous learning strategies in ICT are promoting digital 
self-inclusion as a fluid process of actions and interactions which respond to women's will and capacity for action, being important in their ICT learning experiences.

This study shows that conventional strategies are not the most widely used by women. Hence, doing face-to-face or virtual courses and other activities programmed by associations or groups are not a preferred option for female university students as far as learning ICT is concerned. In fact, these strategies do not coincide with the educational strategies linked to new pedagogies which champion personalization, active learning, collaborative learning and autonomous learning (Gros, 2015). The preferences of these women should therefore be taken into account when looking at the issue of university education.

The study traces different ways that female university students go about learning ICT. It identifies four learning strategies: "intensive extended", "moderate extended", "self-directed/collaborative" and "self-directed". The study by Vergés et al. (2011) showed that women access technological learning via informal channels, at times this may be in parallel to formal education and informal education. In our study, a greater percentage of university students learned in a self-directed, self-taught and intuitive way. Having said this, we have to bear in mind that the most advanced level of digital competence is reached with intensive and moderate extended forms of learning; this means using forms of learning with a variety of frequently recurring strategies. In line with Rebollo-Catalán, Vico-Bosch, et al. (2015), the diversity and heterogeneity of strategies used by women to learn ICT stimulates their digital competence. Thus, learning in a self-directed way alone does not constitute the most effective way of developing digital competence on the internet.

In this sense, university education has to be sensitive to this type of self-directed educational process which is characteristic of women. However, as Gros (2015) states, they need to develop major skills at an earlier stage. Such skills are not acquired spontaneously and should constitute the goal of new pedagogical approaches at university. These new designs should incorporate a wide diversity of strategies, due to their repercussion in the development of digital competence, but they should also be sensitive to the preferences of the women themselves.

Acknowledgments

This research is part of the project "Women as weavers of social networks: Relational Strategies and Digital Inclusion" (Reference: EDU2013-45134-P) financed by the state research plan (MINECO, Spain).

Authors' contributions

All authors read and approved the final manuscript.

\section{Competing interests}

The authors declare that they have no competing interests.

Received: 18 June 2016 Accepted: 30 November 2016

Published online: 03 April 2017

References

Adell, J., \& Castañeda, L. (2012). Emerging technologies, emerging pedagogies? En J. Hernández, M. Pennesi, D. Sobrino y A. Vázquez (Coord.), Tendencias emergentes en educación con TIC (pp. 12-32). Barcelona: Asociación Espiral, Educación y Tecnología.

Aesaert, K., \& van Braak, J. (2015). Gender and socioeconomic related differences in performance based ICT competences. Computers \& Education, 84, 8-25.

Area, M. (2007). Algunos principios para el desarrollo de buenas prácticas pedagógicas con las TICs en el aula. Comunicación y pedagogía: Nuevas tecnologías y recursos didácticos, 222, 42-47.

Cabero, J., \& Llorente, M. (2015). Information and communication technologies (IT): Formative scenarios and learning theories. Revista Lasallista de Investigación, 12(2), 186-193. 
Cobo, C., \& Moravec, J. W. (2011). Invisible learning. Towards a new ecology of education. Barcelona: Collecció Transmedia XXI. Publicacions i Edicions de la Universitat de Barcelona.

Coll, C., Engel, A., Saz, A., \& Bustos, A. (2014). Personal learning environments: Design and use. Cultura y Educación, 26(4), $775-801$.

Cope B., \& Kalantzis, M. (2009). Ubiquitous Learning. Exploring the anywhere/anytime possibilities for learning in the age of digital media. Illinois: University of Illinois Press

Cormier, D. (2008). Rhizomatic knowledge communities: Edtechtalk, Webcast Academy. Dave's Educational Blog. Retrieved from: http://davecormier.com/edblog/2008/02/29/rhizomatic-knowledge-communities-edtechtalkwebcast-academy/

Escofet, A., Albert, A., \& Vilá, G. (2008). Teach and learn with ICT in the University. Colección Cuadernos de Docencia Universitaria. Barcelona: ICE-Octaedro.

Ferrari, A. (2012). Digital competence in practice: An analysis of frameworks. Sevilla: JRC IPTS. doi:10.2791/82116.

García-González, I., Gros, B., \& Escofet, A. (2012). The influence of gender on digital culture of university students. Athenea Digital, 12(3), 95-114.

Gros, B. (2015). The fall of the walls of knowledge in the digital society and the emerging pedagogies. Education in the Knowledge Society (EKS), 16(1), 58-68. doi: 10.14201/eks20151615868.

Jiménez-Cortés, R. (2015). Ubiquitous learning of the young women in the social networks sites and their awareness of learning. Prisma Social, 15, 180-221.

Johnson, L., Adams Becker, S., Estrada, V., \& Freeman, A. (2015). Horizon report: 2015 Higher Education Edition. Reading. Retrieved from http://cdn.nmc.org/media/2015-nmc-horizon-report-HE-EN.pdf

Maquilón, J. J., Mirete, A. B., García-Sánchez, F. A., \& Hernández, F. (2013). Students' assessment of ICT and approaches to learning. Revista de Investigación Educativa, 31(2), 537-554. doi:10.6018/rie.31.2.151891.

Margaryan, A., Littlejohn, A., \& Vojt, G. (2011). Are digital natives a myth or reality? University students' use of digital technologies. Computers \& Education, 56(2), 429-440. doi:10.1016/j.compedu.2010.09.004.

Onrubia, J. (2005). Aprender y enseñar en entornos virtuales: actividad conjunta, ayuda pedagógica y construcción del conocimiento. Revista de educación a distancia. Retrieved from: http://www.um.es/ead/red/M2/conferencia_onrubia.pdf

Rebollo-Catalán, A., Vico-Bosch, A., \& García-Pérez, R. (2015). Women's learning of social networks and their influence on digital competence. Prisma Social, 15, 122-146.

Rebollo-Catalán, A., Mayor-Buzón, V., \& García-Pérez, R. (2015). Las competencias digitales en las redes sociales como indicador de las nuevas alfabetizaciones. Paper presented at CINAIC2015, Madrid, España del 14 al 16 de Octubre.

Rosenthal, R. L. (2008). Older computer-literate women: Their motivations, obstacles, and paths to success. Educational Gerontology, 34(7), 610-626. doi: 1080/03601270801949427.

Sánchez-Vadillo, N., Ortega-Esteban, O., \& Vall-Ilovera, M. (2012). Breaking the gender digital divide. Involved factors in the choice of a technological career. Athenea Digital, 12(3), 115-128.

Siemens, G. (2005). Connectivism: A learning theory for the digital age. International Journal of Instructional Technology and Distance Learning, 2(1), 6. Retrieved from: http://www.elearnspace.org/Articles/connectivism.htm.

UK government's technical report (2012). Research and analysis. Digital Landscape Research. Retrieved from: https:// www.gov.uk/government/publications/digital-landscape-research/digital-landscape-research

Van Deursen, A. J. M., Helsper, E. J., \& Eynon, R. (2014). Measuring digital skills. From digital skills to tangible Outcomes project report. Retrieved from: www.oii.ox.ac.uk/research/projects/?id=112

Vergés, N. (2012). From exclusion to self-inclusion of women in ICT.Motivations, enablers and mechanisms of selfinclusion. Athenea Digital, 12(3), 129-150.

Vergés, N., Hache, A., \& Cruells, E. (2011). Digging in the significance of the internet for the ICT access, uses and desires of women in ICT. Teoría de La Educación. Educación y cultura en la sociedad de la información, 12(2), 105-121.

Zapata-Ros, M. (2015). Theories and models about learning in connected and ubiquitous environments: Bases for a new theoretical model from a critical vision of "connectivism". Education in the Knowledge Society (EKS), 16(1), 69-102. 